\title{
Against Ethnicity: Democracy, Equality, and the Northern Irish Conflict
}

\section{Simon Prince}

\begin{abstract}
The study of the Northern Irish Troubles is dominated by ethnic readings of conflict and violence. Drawing on new scholarship from a range of different disciplines and on fresh archival sources, this article questions these explanations. General theories that tie together ethnicity with conflict and violence are shown to be based on definitions that fail to distinguish ethnic identities from other ones. Their claims cannot be taken as being uniquely or even disproportionately associated with ethnicity. Explanatory models specifically developed for the case of modern Ireland do address that weakness. Yet, this article contends, they rest upon the fallacy that the Catholic and Protestant peoples are transhistorical entities. Political ideas, organizations, and actions cannot be reduced to fixed group identities. This article argues instead that the Troubles centered on a political conflict-one over rival visions of modern democracy. The pursuit of equality, the core value of democracy, led not only to conflicts but also to some of those conflicts becoming violent. Focusing on Belfast in the summer and autumn of 1969, this article sets out how the main political actors asserted competing claims to popular sovereignty and traces how multiple dynamic and intersecting conflicts became arrayed around the central one.
\end{abstract}

\section{INTRODUCTION}

$\mathrm{n}$ a pioneering book on the start of the Troubles (1997), Niall Ó Dochartaigh argued that the "Outbreak of conflict in Yugoslavia" made it "much more widely acceptable to analyze the situation in Northern Ireland as an ethnic conflict." The Troubles looked to Ó Dochartaigh "like a vision of a common European future." By the end of the twentieth century, ethnic approaches to understanding conflict had become intellectual common sense. ${ }^{2}$

Far from being a statement of the obvious, however, describing twenty-firstcentury conflict in ethnic terms was becoming a distortion of reality. The era of

Dr. Simon Prince is a senior lecturer of modern history in the School of Humanities at Canterbury Christ Church University. This article has benefited from comments on an earlier draft by Guy Beiner, Joanna Bourke, Cillian McGratten, Maggie Scull, Sarah Stoller, and Jennie Taylor. Dr. Prince is also grateful to Jeffrey Collins and Holger Hoock, the anonymous readers, and Maureen Garvie of the Journal of British Studies for critical scrutiny. Versions of the argument presented here have been delivered as papers at the University of Oxford and the University of Cambridge. Please direct any correspondence to simon. prince@canterbury.ac.uk.

${ }^{1}$ Niall Ó Dochartaigh, From Civil Rights to Armalites: Derry and the Birth of the Irish Troubles, 2nd ed. (Basingstoke, 2005), 8.

${ }^{2}$ Richard Bourke, "Languages of Conflict and the Northern Ireland Troubles," Journal of Modern History 83, no. 3 (September 2011): 544-78, at 545. 
ethnic pandemonium that some commentators predicted after the fall of the Berlin Wall never arrived. ${ }^{3}$ The Cold War had not contained internal conflicts but instead encouraged them: those years had seen a steady increase in ongoing civil wars. Since superpower support ended, the number of civil wars taking place around the world has fallen into steep decline. ${ }^{4}$ The armed conflicts in what had been Yugoslavia came to a close at the start of the century, with Serbian citizens overthrowing the Serbian regime in a nonviolent revolution in Serbia-an ending that calls into question whether that story should still be read as an ethnic tragedy. ${ }^{5}$

Even before Slobodan Milošević was toppled, prevailing ethnic interpretations of internal conflict were being challenged by scholars from a range of disciplinesamong others, the historian Richard Bourke, the political scientist Stathis Kalyvas, and the sociologist Rogers Brubaker. Inspiration for their revisionist work was often taken from the academic arguments that had brought about "the fall of class" a decade or so earlier. ${ }^{6}$ Just as ethnicity has taken center stage in studies of twentieth-century Ireland, class used to be the actor around which the drama of nineteenth-century Britain was written. ${ }^{7}$ In his 1983 essay "Rethinking Chartism," Gareth Stedman Jones sought to escape "the gravitational pull exercised by the social interpretation"; starting "from what Chartists actually said or wrote" rather than with the concept of class consciousness, he took their preoccupation with politics seriously. ${ }^{8}$

With that essay, Stedman Jones spearheaded a return to politics. Political ideas and institutions were no longer seen as spume on the wave of social and economic realities. ${ }^{9}$ The political is a distinct sphere of human activity where the terms of the life in common are debated, laid down, and contested. It is made up of interrelated sites ranging from street protests in a neighborhood to strategies played out in a formal international organization. As action presupposes thought, political struggle has to be studied in its intellectual context if individuals are to be credited with having

\footnotetext{
${ }^{3}$ Daniel Moynihan, Pandemonium: Ethnicity in International Politics (New York, 1993).

${ }^{4}$ Stathis Kalyvas and Laia Balcells, "International System and Technologies of Rebellion: How the End of the Cold War Shaped Internal Conflict," American Political Science Review 104, no. 3 (August 2010): 415-29.

${ }^{5}$ V. P. Gagnon, The Myth of Ethnic War: Serbia and Croatia in the 1990s (London, 2004), 2, 7, 178; Ivan Rejvoda, "Civil Society versus Slobodan Milošević: Serbia, 1991-2000," in Civil Resistance and Power Politics: The Experience of Non-violent Action from Gandhi to the Present, ed. Adam Roberts and Timothy Garton Ash (Oxford, 2011), 295-316.

${ }^{6}$ Richard Bourke, Peace in Ireland: The War of Ideas (London, 2003); Bourke. "Languages of Conflict"; Stathis Kalyvas, "The Ontology of 'Political Violence': Action and Identity in Civil Wars," Perspectives on Politics 1, no. 3 (September 2003): 475-94; Kalyvas, The Logic of Violence in Civil War (Cambridge, 2006); Kalyvas, "Conflict," in The Oxford Handbook of Analytical Sociology, ed. Peter Hedström and Peter Berman (Oxford, 2009), 592-615; Rogers Brubaker, "Ethnicity without Groups," European Journal of Sociology 43, no. 2 (August 2002): 163-89.

${ }^{7}$ Patrick Joyce, Democratic Subjects: The Self and the Social in Nineteenth-Century England (Cambridge, 1994), 2, 4.

${ }^{8}$ Gareth Stedman Jones, "Rethinking Chartism," in Languages of Class: Studies in English Working Class History, ed. Gareth Stedman Jones (Cambridge, 1983), 90-178, at 94, 106.

9 James Thompson, "After the Fall: Class and Political Language in Britain, 1780-1900," Historical Journal 39, no. 3 (September 1996): 785-806, at 795.
} 
agency. ${ }^{10}$ Returning politics to the study of internal conflict should see also see the slow ebb of ethnicity as a master category.

Bourke saw the Troubles as a contest "over the meaning of popular sovereignty."11 Most scholars of modern Ireland, however, still examine the past through the ethnic lens. "Theory-induced blindness," as the psychologist Daniel Kahneman calls it, tends to set in once a theory has been widely accepted and found to be a useful tool for reasoning. ${ }^{12}$ So Bourke's Peace in Ireland has been misrepresented as a general history of the Troubles, and Kalyvas's research tends to be applied selectively. ${ }^{13}$ Scholars do not quickly and easily put down old tools that have served them well. This article therefore does not set out to prove that the ethnic-conflict interpretation is "false" and that the model based on the problems of giving practical expression to the principle of democratic sovereignty is "true." Instead it attempts to show that a new set of tools for understanding the Troubles is more effective. ${ }^{14}$

The first of the four sections in this article highlights the flaws in general theories of ethnicity as they relate to internal conflict and political violence. The second section goes on to offer brief critiques of the interpretations of violent conflict in modern Ireland put together out of general theories by Tim Wilson and by the sociologist Joseph Ruane and the political scientist Jennifer Todd. Wilson's model, it should be noted, is built on his research on Ulster between 1918 and 1922, but he nonetheless makes clear that he thinks it applies to the Troubles as well. ${ }^{15}$ The third section moves on to the new political approach. Drawing on the work of intellectual historians from the Cambridge School, this section sets out a very short history of the idea of modern democracy and examines how seeking to answer the questions raised by the concept creates conflict. The final section uses previously unseen and overlooked archival sources to show how the new set of tools comes much closer than the old to capturing the complexities, contradictions, and ambiguities of conflict and violence in Belfast at the start of the Troubles. It begins by detailing how the parties to the overarching conflict were mobilized by rival conceptions of democratic legitimacy. The section concludes by exploring incidents of intimate violence from this time and place. Where group-based ethnic interpretations have difficulties with such acts-classing them as either ethnic or criminal-the democratic approach, which restores agency to individuals, understands these incidents as the comings together of politics and everyday conflicts.

\footnotetext{
${ }^{10}$ Susan Pedersen, "What Is Political History Now?," in What Is History Now?, ed. David Cannadine (Basingstoke, 2002); Jon Lawrence, "Political History," in Writing History: Theory and Practice, ed. Stefan Berger, Heiko Feldner, and Kevin Passmore (London, 2003), 183-202; David Craig and James Thompson, introduction to Languages of Politics in Nineteenth-Century Britain, ed. David Craig and James Thompson (Basingstoke, 2013), 1-20; William Novak, "Beyond Max Weber: The Need for a Democratic (Not Aristocratic) Theory of the Modern State," Tocqueville Review 36, no. 1 (2015): 43-91.

${ }^{11}$ Bourke, "Languages of Conflict," 550, 578.

12 Daniel Kahneman, Thinking, Fast and Slow (London, 2011), 277.

${ }^{13}$ Geoffrey Warner, "Putting Pressure on O'Neill: The Wilson Government and Northern Ireland 1964-9," Irish Studies Review 13, no. 1 (February 2005): 13-31, at 13; Cheryl Lawther, Truth, Denial and Transition: Northern Ireland and the Contested Past (Abingdon, 2014), 29; Gemma Clark, Everyday Violence in the Irish Civil War (Cambridge, 2014), 2, 154, 181, 184, 195.

${ }^{14}$ Kahneman, Thinking, Fast and Slow, 288, 314.

${ }^{15}$ Tim Wilson, Frontiers of Violence: Conflict and Identity in Ulster and Upper Silesia, 1918-1922 (Oxford, 2010), 215-16, 219-20; Tim Wilson, "Frank Wright Revisited," Irish Political Studies 26, no. 3 (August 2011): 277-82.
} 


\section{ETHNICITY IS WHAT?}

By the time the first major academic accounts of the early Troubles appeared at the turn of the century, their authors had already come to assume that the concept of ethnicity was so widely known that readers did not need to have it defined. ${ }^{16}$ But the lack of a definition matters here. Causal claims that tie together properties related to ethnic identity with, say, violence cannot be taken as reasonable until it can be shown that these properties are linked uniquely or even disproportionately with ethnicity. However, taking this first step proves surprisingly difficult.

Some scholars of modern Ireland have chosen to adopt the definition worked out by the political scientist Donald Horowitz. ${ }^{17}$ In his influential Ethnic Groups in Conflict (1985), Horowitz holds that "ethnicity is based on a myth of collective ancestry." 18 This definition, though, does not even fit with classifications Horowitz uses in his book. Hindus and Muslims in India, Christians and Muslims in Lebanon, and Creoles and Indians in Guyana and Trinidad do not have myths of common ancestry, yet Horowitz classes all these groups as ethnic categories. Admittedly, "Catholics" and "Protestants" in modern Ireland can be said to possess such myths of collective descent. But for a myth of common ancestry to be the primary defining characteristic of an ethnic group, the successful reception of this myth cannot rest upon any other characteristic that also distinguishes members. ${ }^{19}$ And some criterion external and prior to a myth is always needed as a guide to which materials to hand should be woven into the story. ${ }^{20}$

Any proposed definition based on a common culture again fails to capture the way that ethnic groups are typically classified. Once more, however, the definition does seem to work for "Catholics" and "Protestants." Tim Wilson maintains that "the seminal text here" is Fredrik Barth's introduction to Ethnic Groups and Boundaries. ${ }^{21}$ Barth argues that "cultural features" are employed as "signals and emblems of differences," creating and maintaining boundaries that incorporate and shut out. ${ }^{22}$ Such cultural features, however, can rarely serve as the primary defining characteristics of ethnicity; they generally need to be backed up by descent-based attributes. Indeed, Barth's own postwar case study of the "Pathans" suggests that this identity could not be constituted simply on the basis of "act[ing] out core Pathan values." $\mathrm{He}$

${ }^{16}$ Ó Dochartaigh, From Civil Rights to Armalites, 7; Marc Mulholland, Northern Ireland at the Crossroads: Ulster Unionism in the O'Neill Years, 1960-9 (London, 2000), ix; Thomas Hennessey, Northern Ireland: The Origins of the Troubles (Dublin, 2005), 388.

${ }^{17}$ Ó Dochartaigh, From Civil Rights to Armalites, 8, 10; Peter McLoughlin, "Horowitz's Theory of Ethnic Party Competition and the Case of the Northern Ireland Social Democratic and Labour Party, 1970-79," Nationalism and Ethnic Politics 14, no. 4 (November 2008): 549-78; John McGarry and Brendan O'Leary, The Politics of Antagonism: Understanding Northern Ireland (London, 1993).

18 Ashutosh Varshney, "Ethnicity and Ethnic Conflict," in The Oxford Handbook of Comparative Politics and Ethnic Groups, ed. Carles Boix and Susan Stokes (Oxford, 2007), 274-94, at 274; Donald Horowitz, Ethnic Groups in Conflict (Berkeley, 1985), 52.

${ }^{19}$ Kanchan Chandra, "What Is Ethnic Identity? A Minimalist Definition," in Constructivist Theories of Ethnic Politics, ed. Kanchan Chandra (Oxford, 2012), 51-96, at 77-80.

${ }^{20}$ Guy Beiner, "Probing the Boundaries of Irish Memory: from Postmemory to Prememory and back," Irish Historical Studies 39, no. 154 (November 2014): 296-307.

${ }^{21}$ Wilson, Frontiers of Violence, 14.

${ }^{22}$ Frederik Barth, introduction to Ethnic Groups and Boundaries: The Social Organization of Culture Difference, ed. Frederik Barth, 2nd ed. (Long Grove, 1998), 9-38, at 14, 15. 
concedes, "The acceptance of a strict patrilineal descent criterion is universal."23 Parentage was key in Ireland, too, during the twentieth century. The Ne Temere decree issued by the Roman Curia in 1907 required children of mixed marriages to be raised as Roman Catholics. ${ }^{24}$ However, baptized Protestants who converted to Roman Catholicism and took up the Irish nationalist cause were not accepted on the other side of the boundary, even though they were performing the core values. $^{25}$ Descent counted more than culture. ${ }^{26}$

Kanchan Chandra argues that ethnic identities belong to a wider set of "categories in which descent-based attributes are necessary for membership." 27 Everyone has a range of nominal ethnic identities, those categories in which individuals qualify for membership due to the attributes they have. Ethnic identities are activated when individuals claim membership in a category or when they are placed into one by others. Chandra divides descent-based attributes broadly into three types: those to do with genetics, such as skin color; those that come through cultural inheritance, such as the religion of parents and earlier generations; and those that are acquired as markers of that heritage, such as schooling. A set of rules is also required to separate out ethnic categories from other descent-based ones. Ethnic categories need to be large enough for membership to be impersonal, so as to distinguish them from family. They have to make up only a part of a country's population. If one sibling is eligible for membership at any given place, then all the other siblings must be as well. The qualifying attributes for membership have to be limited to physical features or to the religion, sect, language, dialect, tribe, clan, race, nationality, region, and caste of parents and ancestors. As Chandra acknowledges, these rules are arbitrary and instrumental. ${ }^{28}$

Using this definition, Chandra picks out two properties intrinsically associated with an ethnic category: constrained change and visibility. Ethnic identities can change, even in the short term, yet only within the limits imposed by fixed sets of descent-based attributes. A practiced observer should be able to tell which key attributes an individual has. However, such observers will not always interpret in the same way the categories that these attributes identify. An identical skin-color shade will be read as "black" in the United States, where there is a polar system of categorization, but as "brown" in Brazil, which has a system of categorization based on a color continuum. ${ }^{29}$ Interpretations can also change over time. Brazilian census results show a sizable shift since the 1960s from the categories of Blanco ("white") and Preto ("black") to Pardo ("brown"), in large part because people revised the

\footnotetext{
${ }^{23}$ Frederik Barth, "Pathan Identity and Its Maintenance," in Ethnic Groups and Boundaries, 117-34, at $117,119,123$.

${ }^{24}$ Marianne Elliott, When God Took Sides: Religion and Identity in Ireland-Unfinished History (Oxford, 2009), 138, 229.

${ }^{25}$ See, for example, attitudes toward James Scott, the founder of National Unity. Michael McKeown, The Greening of a Nationalist (Lucan, 1986), 17-20.

${ }^{26}$ Chandra, "What Is Ethnic Identity?" 85-87.

${ }^{27}$ Kanchan Chandra, introduction to Constructivist Theories of Ethnic Politics, 1-47, at 9.

${ }^{28}$ Chandra, "What Is Ethnic Identity?," 58-63.

${ }^{29}$ Kanchan Chandra, "Attributes and Categories: A New Conceptual Vocabulary for Thinking about Ethnic Identity," in Constructivist Theories of Ethnic Politics, 97-131.
} 
way they identified themselves. ${ }^{30}$ Categories are constructed, reconstructed, and discarded-a process that is bottom up as well as top down.

Most scholars working on how ethnic groups are formed accept basic constructivist assumptions: individuals have multiple identities that can change as the result of historical developments. Nonetheless, few scholars researching the effects of ethnicity upon politics have applied these insights. Democracy, according to the standard line of reasoning, must have fluid majorities and minorities if that system is to sustain people's support. Societies divided along ethnic lines are viewed as generally producing "permanent" majorities and minorities, undermining people's support for the system as a whole and encouraging some to step outside its rules. ${ }^{31}$ The existing literature tends to see such competition and antipathy between ethnic groups as bringing with them the threat of violent conflict. Marc Mulholland, for instance, saw the Troubles as a "continuation, and intensification, of the communal struggle." 32 Ethnic identities during a violent conflict are taken as being fixed, automatically salient, and determinative of political behavior. Individuals, writes Kalyvas in summary of this position, "will act in support of organizations claiming to represent their ethnic identity-so much so that individuals and organizations can be conflated into a single actor, the "ethnic group." 33 The result is scholarly accounts that drain the politics from political violence.

Fixity is the property on which arguments about democratic instability and about a greater likelihood of political violence depend; but fixity cannot by definition be reasonably taken to be an intrinsic property of an ethnic category. Ethnic readings of the Troubles either overlook or sidestep this issue. The political scientists John McGarry and Brendan O'Leary argue that ethnic identities are durable - which means they can be treated as if they were fixed. ${ }^{34}$ If they are durable, then this is a puzzle that needs to be solved rather than a fact that can be taken for granted. The answer offered by the anthropologist John Nagle and the political scientist Mary-Alice Clancy is that "conflict hardens identities." 35 Yet constructivism's viability as a theory requires identities to be capable of softening, hardening, or remaining unchanged. ${ }^{36}$ Constructivists in principle thus end up as primordialists in practice.

Another way of understanding the term primordial is to focus on attachments rather than identities. "One is bound to one's kinsman, one's neighbor, one's fellow believer," writes the anthropologist Clifford Geertz. These "primordial bonds" "seem to flow more from a sense of natural-some would say spiritualaffinity than from social interaction." As a "primordially-based 'corporate feeling of oneness' [is for many] the meaning of the term 'self' in 'self-rule," Geertz

\footnotetext{
${ }^{30}$ Melissa Nobles, "History Counts: A Comparative Analysis of Racial/Color Categorization in US and Brazilian Censuses," American Journal of Public Health 90, no. 11 (November 2000): 1738-45; Livio Sansome, Blackness without Ethnicity: Constructing Race in Brazil (Basingstoke, 2003), 1-59.

${ }^{31}$ Chandra, "Introduction," 38-39.

${ }^{32}$ Mulholland, Northern Ireland at the Crossroads, 164.

${ }^{33}$ Stathis Kalyvas, "Ethnic Defection in Civil War," Comparative Political Studies 41, no. 8 (August 2008): 1043-68, at 1043 .

${ }^{34}$ John McGarry and Brendan O'Leary, "Consociational Theory, Northern Ireland's Conflict, and Its Agreement 2," Government and Opposition 41, no. 2 (March 2006): 249-77, at 271.

${ }^{35}$ John Nagle and Mary-Alice Clancy, Shared Society or Benign Apartheid?, Understanding Peace-Building in Divided Societies (Basingstoke, 2010), 15.

${ }^{36}$ Kalyvas, "Ethnic Defection in Civil War," 1046.
} 
argues, "a sovereign civil state" brings with it the risk of "communal uproars."37 McGarry and O'Leary are primordialists in this second sense. Their ethno-national communities are so strong and long-lasting because they are based on the "givenness" of kinship bonds. ${ }^{38}$

Political conflict, however, cannot be ripped from its intellectual context. ${ }^{39}$ People consciously construct political ties out of normative principles and modify them under the pressures of the political process. Collective action requires political organizations and ideologies. ${ }^{40}$ Ethnic conflict therefore cannot reasonably be distinguished from political conflict. Indeed, during the course of the Troubles, individuals who supposedly possessed the same ethnic identity/ies did not behave in the same ways. Some "Catholics" joined the security forces, and some "Protestants" campaigned and on occasion fought for a united Ireland. Individuals could even change sides: a small minority of Provisional Irish Republican Army (IRA) volunteers became British spies and informers. ${ }^{41}$ Such "defections" matter, even though the low numbers involved might suggest otherwise. Human beings are not fully rational, so the fear of "defection" was not proportional to the probability of the threat. ${ }^{42}$ The Provisional IRA targeted for death or assault hundreds of people from the community it claimed to be defending. ${ }^{43}$ This "Catholic-on-Catholic" violence undermines the argument that so many different individuals and organizations can be treated as if they were a unitary actor. ${ }^{44}$ (The number of "defections" may have in fact been higher-much higher. The political scientist Kevin Bean contends that twisted policy paths from the late 1980s onwards created the political space for the Provisional Republican movement to work with the British state. Pro-Agreement Republicans did not become "Protestants," yet they still gave up in practice their claim to be the legitimate rulers of the island and went into coalition with unionists to govern part of the United Kingdom. ${ }^{45}$ )

\section{HOMEGROWN THEORIES OF ETHNIC CONFLICT}

Neither Tim Wilson nor Joseph Ruane and Jennifer Todd simply apply existing models of the effects of ethnicity. Instead, they have drawn on general theories to develop arguments for a particular time and place: modern Ireland. Wilson's "starting point" is that Ulster society from the seventeenth century onwards was divided between "two clearly-defined communities." When their struggle to dominate each

\footnotetext{
${ }^{37}$ Clifford Geertz, "The Integrative Revolution: Primordial Sentiments and Civil Politics in the New States," in The Interpretation of Cultures: Selected Essays, ed. Clifford Geertz (New York, 1973), 255310 , at $259,260,270$.

${ }^{38}$ John McGarry and Brendan O'Leary, Explaining Conflict in Northern Ireland: Broken Images (Oxford, 1995), 354-45.

${ }^{39}$ Quentin Skinner, Visions of Politics, vol. 1, Regarding Method (Cambridge, 2002), xi.

${ }^{40}$ Bourke, "Languages of Conflict," 549-50, 563-65.

${ }^{41}$ Thomas Leahy, "The Influence of Informers and Agents on Provisional IRA Military Strategy and British Counter-Insurgency Strategy, 1976-94," Twentieth Century British History 26, no. 1 (March 2015): 122-46.

${ }^{42}$ Kahneman, Thinking, Fast and Slow, 316.

${ }^{43}$ Richard English, Armed Struggle: The History of the IRA (Macmillan, 2003), 361, 388.

${ }^{44}$ Kalyvas, "Ethnic Defection in Civil War," 1050.

${ }^{45}$ Kevin Bean, The New Politics of Sinn Féin (Liverpool, 2007).
} 
other turned violent-which it did every decade or so-killers selected victims as "representatives of their community, not as individuals." Everyone could be identified as belonging to one of the two ethnic groups; everyone was a potential victim; everyone had a reason to be afraid. By the end of the nineteenth century, the tit-for-tat cycles of representative violence had led to the emergence of "deterrence communities." Periods of peace were simply cold wars. However, "the trouble with deterrence threats," as Wilson explains, "is that sooner or later they have to be acted upon." Each side in these violent conflicts was seeking to force the other one to back down by inflicting unbearable levels of suffering and by showing it could take the pain. ${ }^{46}$

Wilson concludes that "conflict on the ethnic frontier" operated "essentially like a large-scale system of feud." 47 This point is not developed much further, so it helps to read Frontiers of Violence alongside the sociologist Roger Gould's work on violent feuds in American cities and on Corsica. The great majority of murders (one recent US estimate is 78 percent ${ }^{48}$ ) involve lovers, family members, friends, acquaintances, or neighbors. Motives for a very large proportion of these killings seem to be trivial matters. Gould sees in these facts signs that "interpersonal violence [is] a product of social relations.” Intimacy necessarily entails frequent contact between individuals, and these interactions end up generating informal hierarchies. Though informal, these hierarchies are not insignificant-as is shown by the value that humans have placed on honor, respect, and popularity. Feuds arise when an existing hierarchy is challenged; competition over social status tends to happen when people think the rankings have become unclear. Gould holds that groups relate to each other in much the same way as individuals do, and can feud with each other too. During times of political instability, some groups view the resulting disruption to social relations as a ladder to a higher ranking. ${ }^{49}$ Such a pattern appears to apply to Northern Ireland, where-as Wilson points out - the Irish Revolution, the labor militancy of the mid-1930s, and the civil rights movement all coincided with serious rioting. ${ }^{50}$

There is more rather than less interpersonal violence in feuding societies, even though individuals know that such acts carry the risk of sparking collective violence. Gould believes that this surprising fact is due to people also having individual interests that set them apart from fellow group members and that they set above the common good. ${ }^{1}$ While Wilson does recognize that "personal feelings of hatred and revenge" play a part in "grassroots violence," he nonetheless minimizes their importance. Between these base emotions and the "political stratosphere," according to Wilson, lies the much larger space of ethnic struggle. He insists that "any member of an opposing community will do as a victim."52 Indeed, the concept of ethnic conflict can only make sense if group members can be switched for each other. On those

${ }^{46}$ Wilson, Frontiers of Violence, 196-220.

47 Ibid., 215.

${ }^{48}$ Alexia Cooper and Erica Smith, Homicide Trends in the United States, 1980-2008, prepared by the US Department of Justice, Bureau of Justice Statistics, Open-file report NCJ 236018 (Washington, DC, 2011), http://www.bjs.gov/content/pub/pdf/htus8008.pdf.

${ }^{49}$ Roger Gould, Collision of Wills: How Ambignity about Social Rank Breeds Conflict (London, 2003), 4, $17,66,86$.

${ }^{50}$ Wilson, Frontiers of Violence, 215.

${ }^{51}$ Gould, Collision of Wills, 116, 118.

${ }^{52}$ Wilson, Frontiers of Violence, 206, 220. 
occasions when victims have been targeted for motives that go beyond group attributes in any way-a low threshold to meet-the violence cannot then be classed as simply ethnic. ${ }^{53}$

Individual interests also pose internal obstacles to group unity. Bourke references here Mancur Olson, the economist who formalized the "collective action problem." 54 Put simply, the problem holds that "rational, self-interested individuals will not act to achieve their common or group interests." 55 They will seek instead to free ride. Explaining the outbreaks of collective violence on the streets of Belfast requires that this problem be either resolved or reformulated. Wilson's answer is polarization. Everyone living in the northeast of Ireland clustered around one of two distant poles; in times of rising tension, people were pulled closer together in groups, and groups were pushed further apart. For self-interested individuals, the rational choice was to seek their own personal security through collective action. As a result, writes Wilson, "party politics faithfully reflected communal polarization," and each community "entertained a strong sense of ownership over its 'defenders." Whenever this cold war turned hot, the violence "jump[ed] back and forth between the poles of rival communities."56

Although polarization provides a plausible explanation for violence, it is open to a number of challenges. Drawing upon evidence from the early Troubles, Bourke demonstrates that "hostility was an effect of conflict rather than its cause." 57 And research suggests that in societies where there are high levels of division, this division has not significantly increased the likelihood of violent conflict. ${ }^{58}$ Moreover, polarization does not appear to be simply black and white: there is always a swathe of gray between the two poles where the majority of people cluster. Individual and group interests will only ever be tightly aligned for a small minority. There is wide variation, too, in the emotions the same situation can elicit. Furthermore, people will not respond to similar emotions in identical ways. ${ }^{59}$ Anyway, as Bourke underlines, "Common feeling is not sufficient to unite individual wills into a coherent plan of action."60

Wilson's concept of polarization owes much to the ideas of Carl Schmitt, in particular the philosopher's view that "security depended upon enforcing clear-cut distinctions between friends and enemies." The friend-enemy distinction, according to Schmitt, "denotes the utmost degree of intensity of a union or a separation": the willingness to die for the group and to kill members of the other group. All political actions and motives can be reduced to this ultimate distinction. Wilson comes very

${ }^{53}$ Kalyvas, "Ontology of 'Political Violence," 481.

${ }^{54}$ Richard Bourke, "Antigone and After: 'Ethnic' Conflict in Historical Perspective," Field Day Review 2 (2006): 168-94, at 180; Bourke, "Languages of Conflict," 565.

${ }^{55}$ Mancur Olson, The Logic of Collective Action: Public Goods and the Theory of Groups, rev. ed. (Cambridge, MA, 1971), 2.

${ }^{56}$ Wilson, Frontiers of Violence, 46, 109, 197, 198.

${ }^{57}$ Richard Bourke, Peace in Ireland: The War of Ideas, rev. ed. (London, 2012), xiv; Bourke, Peace in Ireland (2003), 75, 102.

${ }^{58}$ David Laitin, "Secessionist Rebellion in the Former Soviet Union," Comparative Political Studies 34, no. 8 (October 2001): 839-61; Paul Collier et al., Breaking the Conflict Trap: Civil War and Development Policy (Washington, DC, 2003), 58-60.

59 Kalyvas, "Conflict," 600-2.

${ }^{60}$ Bourke, Peace in Ireland (2012), xiv, xv. 
close to endorsing this position, not least in his statement that "to know the communal identity of the victim was to know the communal identity of the perpetrator."61 For Wilson, the communal divide has for over a century shaped everything; nothing in that time has reshaped the communal divide. In this effectively static interpretation, explains Bourke, "Antagonistic communities preserve their group integrity as they seamlessly progress through history, transmitting their hostility down the generations." 62 Polarization for Wilson acts as a protective bubble. But, as explained in the previous paragraph, the concept is flawed: it cannot take the pressure that this argument places upon it, and the bubble bursts. Wilson is left violating the basic constructivist assumption that identities can change as a result of historical developments.

In Wilson's static society, the spatial context remains constant. It must, because the argument is built upon the political scientist Frank Wright's concept of the "ethnic frontier."63 In Wright's words, ethnic frontiers are "places where the populations of citizens and natives were fairly evenly balanced." "Citizens" have ethnic ties to the dominant group in the metropolitan center; "natives" may or may not have ethnic ties to the majority population in a bordering state. Wright takes four of his cases from East Central Europe-Bohemia and Prussian Poland-where, from the 1880 s onwards, contemporaries were using the term "language frontiers." 64 Recent scholarship that draws upon Brubaker has shown that these were discursive rather physical spaces. "Far from constituting sites of daily battles between nations," writes Pieter Judson, "so-called language frontiers were often populated by rural people who did not automatically translate division in language use into divisions of self-identification." Using a language was instead a functional question, and a range of both formal and informal institutions had been created to bridge the gap. ${ }^{65}$ Here were spaces in which people lived, worked, traded, socialized, and slept together - regardless of what language they first spoke to their parents. ${ }^{66}$ Nationalist activists, in their struggle to make everyone else national, found themselves frustrated again and again by popular resistance to their preferred category. Czech nationalists complained in 1908, "On the language frontier, we must not only fight with the Germans, but also with renegades and with Czech apathy and national indifference."67 These conflicts were contingent and political rather than the natural outcome of underlying ethnic realities. The gradual expansion of the franchise in imperial Austria had resulted in political movements competing with each other to mobilize ever more people. Nation building was in effect party building, and it

${ }^{61}$ Wilson, Frontiers of Violence, 193, 213; Carl Schmitt, The Concept of the Political, trans. George Schwab, rev. ed. (Chicago, 2007), 26.

${ }^{62}$ Bourke, "Languages of Conflict," 567.

${ }^{63}$ Wilson, Frontiers of Violence, 18.

${ }^{64}$ Frank Wright, Northern Ireland: A Comparative Analysis (Dublin, 1987), 1.

${ }^{65}$ Pieter Judson, Guardians of the Nation: Activists on the Language Frontiers of Imperial Austria (Cambridge, MA, 2006), 3.

${ }^{66}$ Tara Zahra, Kidnapped Souls: National Indifference and the Battle for Children in the Bohemian Lands, 1900-1948 (Ithaca, 2008), 1-3.

${ }^{67}$ Tara Zahra, "Imagined Noncommunities: National Indifference as a Category of Analysis," Slavic Review 69, no. 1 (Spring 2010): 93-119, at 93. 
required the same levels of commitment and patience. ${ }^{68}$ Neither identifications nor frontiers were stable and fixed.

Wright's depiction of imperial space as fixed has been superseded too. Undercutting the metropole-colony divide, Tony Ballantyne has argued that the British Empire should be viewed as "a complex agglomeration of overlapping webs." Individual empire builders were constantly spinning new threads, often in response to old ones being broken or destroyed. Irish men and women from all backgrounds made up a sizable proportion of those who took up the opportunities and assumed the risks presented by this dynamic environment. ${ }^{69}$ The movement of people, goods, and ideas around the empire not only tied points in imperial space to London but also tied them directly to each other. ${ }^{70}$ Irish economic, social, cultural, religious, and familial networks flowed through the whole empire rather than just to Britain and back. For Catholic churches in the English-speaking world and Catholic missions in Africa and Asia, Dublin rather than London was the central node in their spiritual network. ${ }^{71}$ Empire also shaped resistance to empire. Nationalist and anticolonial actors sought each other out to share experiences, ideas, and resources. ${ }^{72}$ In this networked space, identifications and places were more the unique and ever-changing comings together of many different trajectories than they were stable and bounded entities. ${ }^{73}$

Regional and transnational studies are two of the ways in which historians have been trying to break free of the discipline's conventional focus on the nation. Most historians were nation builders in the nineteenth and early twentieth centuries. By contrast, from the 1940s onwards, historians believed their profession was waging what T. W. Moody called a "war against servitude to myth." "74 Moody did not question that a people had a connection to its collective past, but he was seeking to replace a fictitious version of that link with the real thing. ${ }^{75}$ Even after the discipline moved on to picking apart imagined communities and collective memories, however, most scholars still wrote as if peoples were the subjects and agents of European history. ${ }^{76}$

${ }^{68}$ Pieter Judson, The Habsburg Empire: A New History (Cambridge, MA, 2016), 270-74.

${ }^{69}$ Hilary Carey, God's Empire: Religion and Colonialism in the British World, c. 1801-1908 (Cambridge, 2011), 124-45.

${ }^{70}$ Tony Ballantyne, Orientalism and Race: Aryanism in the British Empire (Basingstoke, 2002), 14-15.

${ }^{71}$ Colin Barr, "Imperium in Imperio': Irish Episcopal Imperialism in the Nineteenth Century," English Historical Review 123, no. 502 (June 2008): 611-50; Edmund M. Hogan, The Irish Missionary Movement: A Historical Survey, 1830-1980 (Dublin, 1990).

${ }^{72}$ Tony Ballantyne and Antoinette Burton, Empires and the Reach of the Global, 1870-1945 (Cambridge, MA, 2012), 132; Matthew Kelly, "Irish Nationalist Opinion and the British Empire in the 1850s and 1860s," Past and Present 204, no. 1 (August 2009): 127-54.

${ }^{73}$ Alan Lester, "Imperial Circuits and Networks: Geographies of the British Empire," History Compass 4, no. 1 (January 2006): $124-41$, at 135.

${ }^{74}$ Stefan Berger, "A Return to the National Paradigm? National History Writing in Germany, Italy, France, and Britain from 1945 to the Present," Journal of Modern History 77, no. 3 (September 2005): 629-78, at 631, 634; T. W. Moody, "Irish History and Irish Mythology", in Interpreting Irish History: The Debate on Historical Revisionism, 1938-1994, ed. Ciaran Brady (Dublin, 1994), 71-86, at 71 (previously published as Moody, "Irish History and Irish Mythology," in Hermathena, no. 124 [Summer 1978]: 7-24).

${ }^{75}$ Richard Bourke, "Historiography," in The Princeton History of Modern Ireland, ed. Richard Bourke and Ian McBride (Princeton, 2016), 271-91, at 274-75.

${ }^{76}$ Zahra, "Imagined Noncommunities," 96-97. 
Nationalists, however, had built peoples as well as nations. While they insisted that a "new" or "revived" nation came out of an "old" people, activists were in fact developing the concepts of nation and people in conjunction with each other. ${ }^{77}$ Scholars have too often taken these political claims to common ancestry as evidence of real continuities across time. ${ }^{78}$ Wilson describes the "Catholic/Protestant confrontation" as taking "shape" in the seventeenth century and then displaying "extraordinary longevity."79 But, as Louis Cullen has demonstrated for the eighteenth century, the "abstract Irish 'catholic' "and the "abstract Irish 'protestant ... did not exist." 80 National-if not nationalist_-readings of the past present the stories of fictional peoples. Such readings replace the complicated developments produced by protean and shifting loyalties with the simple struggles of nonpolitical ethnic groups. ${ }^{81}$

Brubaker warns against treating ethnic groups as "things in the world"-as "substantial entities to which interests and agency can be attributed." 82 According to this interpretation, when Wilson writes that "it took until June 1922 for the Catholic community to accept that it could not sustain its side of the 'murder competition,"' he is engaging in the reification of the Catholic community. ${ }^{83}$ Ethnic groups, according to Brubaker, may not be real or ongoing entities, but ethnicity may be used to make situational communities. Indeed, given that "groupness" is variable and contingent, ethnicity is an event-something that may or may not happen. ${ }^{84}$ For example, Elizabeth Gilmour, a resident of Ardoyne, displayed the Union flag from her house in the run-up to the Orange parades of July 1969. However, she also acted as a guarantor for a family from a different faith who wanted to move into her street, was a frequent visitor to the parochial house, and entertained Catholic priests in her front room. ${ }^{85}$ Thinking about ethnicity as relational and dynamic calls into question how useful the concept of ethnicity still is to scholars. Brubaker concludes that "we may end up not studying ethnicity at all." 86

Todd regards Brubaker's arguments as a "revolution," and her response is to mount a counterrevolution. ${ }^{87}$ She and Ruane accept that ethnicity is a way of

77 Jeremy King, Budweisers into Czechs and Germans: A Local History of Bohemian Politics, 1848-1948 (Princeton, 2002), 6-7.

${ }^{78}$ Bourke, "Historiography," 285; Richard Handler, Nationalism and the Politics of Culture in Quebec (Madison, 1988), 8.

${ }^{79}$ Wilson, Frontiers of Violence, 22-23.

${ }^{80}$ Louis Cullen, "Catholics under the Penal Laws," Eighteenth-Century Ireland 1 (1986): 23-36, at 24-25.

${ }^{81}$ Jeremy King, "The Nationalization of East Central Europe: Ethnicism, Ethnicity, and Beyond," in Staging the Past: The Politics of Commemoration in Habsburg Central Europe, 1848 to the Present, ed. Maria Bucur and Nancy Wingfield (West Lafayette, 2001), 112-52, at 129.

82 Brubaker, "Ethnicity without Groups," 164, 174-75.

${ }^{83}$ Wilson, Frontiers of Violence, 197.

${ }^{84}$ Rogers Brubaker et al., Nationalist Politics and Everyday Ethnicity in a Transylvanian Town (Princeton, 2006), 6-12.

${ }^{85}$ Public Inquiry into the Acts of Violence and Civil Disorder in Northern Ireland (hereafter Scarman Inquiry), Day 46, 2 March 1970 (Rev. Charles Sansom), pp. 64-65, Institute for Advanced Legal Studies (hereafter IALS); Scarman Inquiry, Day 48, 4 March 1970 (Father Columb O'Donnell), pp. 28-29, IALS; Scarman Inquiry, Day 49, 5 March 1970 (Mary Baillie), p. 84, IALS; Scarman Inquiry, Day 59, 27 April 1970 (Father Marcellus Gillespie), pp. 36, 63, IALS.

86 Brubaker, "Ethnicity without Groups," 186.

${ }^{87}$ Jennifer Todd, "Trajectories of Identity Change: New Perspectives on Ethnicity, Nationality and Identity in Ireland," Field Day Review 3 (2007): 82-93, at 83. 
perceiving the world, but they insist that "conceptual food" can fatten up this "thin category" to render it useful again In Ireland, religious, colonial, national, and other cultural and political institutions, practices, and beliefs thickened and deepened an overarching ethnic division. The result was a "system of relationships" based on "cultural difference, power relations, and communal belonging"; each of these overlapped with and reinforced the others. Ruane and Todd trace the "moment of crystallization" to the end of the seventeenth century, when the "British Protestant minority" won their "definitive victory." The system provided strong inducements for actors to operate within its rules and not to step outside of them. These positive and negative feedback loops ensured that the system reproduced itself across time and absorbed external shocks such as "modernization, industrialization, and democratization." Elements were added and discarded over the centuries, yet the system kept the basic relations the same. Partition merely succeeded in limiting the system to the northeast of the island. Path dependence, then, rather than polarization is what keeps Ruane and Todd from violating the basic constructivist assumption that identities can change as a result of historical developments. "Solidary, bonded, easilymobilized populations with intense communal identification" were "emergent properties of the system." The strength and resilience both of the "Catholic" and "Protestant" communities and of the conflict between them was due to "systematicity" rather than to specific properties of "ethnicity." 88 The banners of the counterrevolution bear the motto "Groups without Ethnicity."

Ruane and Todd once more reduce politics to spume on the wave of history and treat peoples as transhistorical entities. What is different about their model, however, is that their groups are products of an institutionalized system. In theory, this system could shape politics and ensure continuity. Ruane and Todd ground their arguments in the ideas of path dependence and rational choice. ${ }^{89}$ Path dependence started out as a way of explaining the development and diffusion of technologies such as videocassette recorders. In the stretched version, chance events set into motion institutional patterns where increasing returns lead to equilibrium across history. But the years from the Tudor conquest to the War of the Two Kings cannot at all fairly be seen as what the sociologist James Mahoney calls "a highly improbable concurrence of events." $" 90$ The huge changes brought about during this period were more likely to be what shaped later actions and identifications than were the system's mechanisms of reproduction. There are cracks in the second foundation — rational choice — too. Humans have evolved to be social animals, acting on a sense of fairness instead of pursuing self-interest. ${ }^{91}$ Anyway, as Kahneman has shown, human rationality is bounded. ${ }^{92}$ Like polarization, this path appears to be a dead end.

\footnotetext{
${ }^{88}$ Joseph Ruane and Jennifer Todd, "The Roots of Intense Ethnic Conflict May Not in Fact Be Ethnic: Categories, Communities and Path Dependence," European Journal of Sociology 45, no. 2 (August 2004): 209-32, at 216-20, 224-27; Todd and Ruane, "Path Dependence in Settlement Processes: Explaining Settlement in Northern Ireland," Political Studies 55, no. 2 (June 2007): 442-58, at 448-51.

${ }^{89}$ Ruane and Todd, "Roots of Intense Ethnic Conflict," 226.

${ }^{90}$ James Mahoney, "Path Dependence in Historical Sociology" Theory and Society 29, no 4 (August 2000): 507-48, at 535 .

${ }^{91}$ Brian Boyd, On the Origin of Stories: Evolution, Cognition, and Fiction (Cambridge, MA, 2009), 62.

92 Daniel Kahneman, "Maps of Bounded Rationality: Psychology for Behavioral Economics," American Economic Review 93, no 5 (December 2003): 1449-75.
} 


\section{DEMOCRACY, EQUALITY, AND CONFLICT}

How, then, should the Troubles be explained? This article argues that it centered on a political conflict - one over competing visions of modern democracy. Such a claim may seem odd, given that democracy tends to be viewed today as the basis for peace within and between states. However, even briefly studying the historical context in which modern democracy was developed and debated shows how building the concept into practices makes conflict more likely.

In Leviathan, Thomas Hobbes reasoned that a political covenant is an agreement in which all individual members of the throng contract with every other one to authorize a single man or an assembly to act in their name. The many of the multitude becomes one through the "Unity of the Representer" and owns in common all its words and actions. The political covenant thus brings into being two artificial persons: the author (the state) and the actor (the sovereign). ${ }^{93}$ A century later, Jean-Jacques Rousseau embraced the Hobbesian notion of a unitary, absolute, and indivisible sovereign, while at the same time rejecting the idea that sovereignty could be represented. The "public person" formed by Rousseau's social contract is called "State when it is passive, Sovereign when active." The individual in this body politic is kept free from domination thanks to the rule of law, as "obedience to the law one has prescribed to one's self is freedom.” For this setup to work, however, Rousseau had to imagine that his republic had a patriotic population of equal standing that shared the same morals, a separate government run by an elected aristocracy, a civil religion, and a set of fundamental laws put in place by a godlike "Lawgiver."94 In other words, he had to imagine the impossible. "I see no tolerable mean," he subsequently conceded, "between the most austere Democracy and the most perfect Hobbesism." $" 95$

Nonetheless, at the start of the French Revolution, Emmanuel Joseph Sieyès believed that there was indeed an answer to Rousseau's "great problem of Politics." The solution was to see representation as the basis for liberty rather a threat to it. In a commercial society, individuals have goods and services provided for them by representative labor. Humans have political needs too. They therefore come together in a single body with a common will as a "nation"- a term used by Sieyès, for tactical reasons, as a synonym for "state." When a nation grows in population and territory to a certain point, the real common will necessarily gives way to the representative common will. This is the "constituting power"-that is to say, the sovereign-that has been entrusted with creating a constitution. In turn, the "constituted power," the government, represents both the nation as a whole and its many different members. Representation links the public functions of the nation to the non-political activities of individuals; it also guards the lives and goods of the nation's members

93 Thomas Hobbes, Leviathan, ed. Richard Tuck (Cambridge, 1996), 111-15; Quentin Skinner, "Hobbes and the Purely Artificial Person of the State," Journal of Political Philosophy 7, no 1 (March 1999): 1-29.

${ }^{94}$ Jean-Jacques Rousseau, "The Social Contract," in The Social Contract and Other Later Political Writings, ed. and trans. Victor Gourevitch (Cambridge, 1997), 39-152.

${ }^{95}$ Jean-Jacques Rousseau, "Letter to Mirabeau, 26 July 1767," in The Social Contract, 268-71; Philip Pettit, "Rousseau's Dilemma," in Engaging with Rousseau Reaction and Interpretation from the Eighteenth Century to the Present, ed. Avi Lifschitz (Cambridge, 2016), 168-88. 
against abuses of power. ${ }^{96}$ Five months after What Is the Third Estate? appeared, Sieyès and the other commoner deputies met without the first two orders, adopted the name National Assembly, began drafting a new constitution for France. ${ }^{97}$

By the close of the eighteenth century, then, what Bourke classes as the "constitutive elements" of modern democracy_- "popular sovereignty and representation, the idea of the people and the concept of the state" - were already in place. ${ }^{98}$ So too were the controversies around which the Troubles and indeed most modern political conflicts have revolved. How should the fictional community of the state be imagined? What form should the representation of its sovereignty take? Both Hobbes and Sieyès had based the state/nation upon existing countries: composite monarchies whose borders had been shaped by military might, marriage, and maleficence. Since the state is the indirect sovereignty of the people and abstract representation is how that sovereignty is exercised, nothing other than politics is left to define the people. Such reasoning raises the problems of putting the political before the people and of promoting chance over choice. What were the people before the state was constructed? What will the people be after the state is dissolved? Are those individuals who are unhappy with where history has put the state's boundaries free to join together in pursuit of a state of their own choosing? Put simply, how should the people-yet another abstract-be imagined?99

In modern Ireland, these questions have produced a range of different answers over the years. At events to mark Bastille Day in 1791, Irish patriot groups across Ulster embraced what Ian McBride terms the "new understanding of the nation as a rational, sovereign community, progressing through time in intellectual and moral character and exercising the right to reshape its political forms accordingly." Irish nationalists have continued to claim that the Irish nation, understood as a cultural group, is the people: the Irish nation/people existed before the British state and thus has the right to secede from it to form a state of its own. Constitutional nationalists once campaigned to pool this sovereignty within a federal system. After partition, however, those in the North shifted their allegiance to an all-Ireland setup. "The idea of an independent Irish republic," notes McBride, was also "an invention of the 1790s." Beginning with the French-backed United Irishmen, republicans have aspired to establish a state that is both wholly united and completely separate from England. The road they have been taking to the Irish Republic, though, keeps twisting, branching off, and dividing them up. Physical-force republicans style themselves

${ }^{96}$ Emmanuel Joseph Sieyès, "What Is the Third Estate?" in Sieyès, Political Writings, ed. and trans. Michael Sonenscher (Indianapolis, 2003), 92-162; Sonenscher, introduction to Sieyès, vii-lxiv; Duncan Kelly, "Popular Sovereignty as State Theory in the Nineteenth Century," in Popular Sovereignty in Historical Perspective, ed. Richard Bourke and Quentin Skinner (Cambridge, 2016), 270-96, at 274-76.

${ }_{97}$ Timothy Tackett, Becoming a Revolutionary: The Deputies of the French National Assembly and the Emergence of a Revolutionary Culture (Princeton, 1996), 146-48.

${ }^{98}$ Richard Bourke, "Nationalism, Balkanization and Democracy," in Schleifspuren. Lesarten des 18 Jahrbunderts. Festschrift fur Eckhart Hellmuth ed. Anke Fischer-Kattner (Munich, 2011): 77-89, at 89.

${ }_{99}$ Bourke, Peace in Ireland (2003), x, 274-75, 314; Bernard Yack, "Popular Sovereignty and Nationalism," Political Theory 29, no 4 (August 2001): 517-36; Istvan Hont, "Jealousy of Trade: An Introduction," in Jealousy of Trade: International Competition and the Nation-State in Historical Perspective, ed. Istvan Hont (Cambridge, MA, 2005), 1-156, at 140-47, 155; David Dwan, "Romantic Nationalism: History and Illusion in Ireland," Modern Intellectual History 14, no. 3 (November 2017): 717-45. 
the provisional representatives of the people's will, holding its sovereignty in trust until such time as an all-Ireland vote elects a constituting power. In response to the republican rising of 1798, the British government brought about the union of the two kingdoms' parliaments. For unionists, the United Kingdom is the state and the Crown-in-Parliament exercises sovereignty. This answer is in keeping with the way Jonathan Swift and other Anglo-Irish pamphleteers identified "the people" with political institutions. ${ }^{100}$ Following the creation of Northern Ireland, unionists have tended to want the sovereign to devolve some public functions to the province. Loyalists, during moments of insurrection such as those in 1912 and 1974, stretch democratic principles even further than republicans do with their insistence that they know the will of the majority of the people. ${ }^{101}$ This insistence elides the distinction between a democratic government-selected on the basis of the majority principle - and a state — understood as a contract of all with all. ${ }^{102}$ Rejecting Hobbes and Sieyès altogether, revolutionary socialists, who played a significant part in the start of the Troubles, hold that humanity, which is to say the workers of the world, needs to be free of both representation and the state. ${ }^{103}$

The secondary elements of modern democracy-notably, the franchise and political parties-introduced further complications. The questions of who could vote in elections and who could sit in legislative assemblies led to politically organized sets of answers. Over the course of the 1820s, Daniel O'Connell's Catholic Association, which aimed at ending the Anglican monopoly on government, became what Richard English calls "the first truly popular, mass-democratic organization."104 At the end of the century, the demand for women's suffrage provided an issue around which feminist activists built political campaigns and networks. ${ }^{105}$ Extending the franchise beyond men of property changed the political system. The Second and Third Reform Acts, together with the advent of the secret ballot, made it possible for the Irish Parliamentary Party to return eight-six MPs in the 1885 general election. ${ }^{106}$ This does not mean, however, as Michael Walzer puts it, that "bring[ing] the 'people' into political life" sees them "arrive ... marching in tribal ranks."107 Parties do not reflect pre-existing cultures or classes; instead, they claim to represent the interests of their constituency. Yet again representation is indirect: parties push their own constructions of those interests, often denying and excluding the ways in which individuals really view their wants and needs. ${ }^{108}$ Indeed, parties-along with other organizations such as state agencies, churches, labor unions, interest groups, and paramilitaries-are the principal actors in the drama of modern

${ }^{100}$ Ian McBride, Eighteenth Century Ireland (Dublin, 2009), 303, 372, 379.

${ }^{101}$ Bourke, Peace in Ireland (2003), 190-93, 220.

102 Bourke, "Languages of Conflict," 573-74.

${ }^{103}$ Istvan Hont, "The Permanent Crisis of a Divided Mankind: 'Contemporary Crisis of the Nation State' in Historical Perspective,” Political Studies 42, no. S1 (August 1994): 166-231, at 223.

${ }^{104}$ Richard English, Irish Freedom: The History of Nationalism in Ireland (London, 2006), 128.

${ }^{105}$ Maria Luddy, "Feminism," in Princeton History of Modern Ireland, 470-89, at 476.

106 Bourke, Peace in Ireland (2003), 395.

${ }^{107}$ Michael Walzer, "The New Tribalism: Notes on a Difficult Problem," in Theorizing Nationalism, ed. Ronald Beiner (Albany, 1999), 205-18, at 206.

108 Adam Przeworski and John Sprague, "Party Strategy, Class Organization, and Individual Voting," in Capitalism and Social Democracy, ed. Adam Przeworski (Cambridge, 1985), 99-134, at 101. 
politics. ${ }^{109}$ That said, people are not passive participants in this relationship, as they can seek to reform the parties that claim to speak for them, or they can seek out another party of their own choosing. Moreover, parties are themselves made up of ambiguous relationships always in the process of being renegotiated. ${ }^{110}$ For example, during the autumn of 1966, backbench Unionist MPs staged a somewhat successful revolt against the party leadership for taking away functions from local councils and for taking decisions in an authoritarian manner. ${ }^{111}$

Putting the concept of modern democracy into practice not only generates conflicts, it also risks violence. Bourke argues that this "lethal potential" stems from democracy's "core value" of equality.112 "The equality in question," he writes, "involves 'equal' participation in rule, meaning a proportionate, but not an identical, share." 113 Individuals assess themselves against everyone else they encounter, striving to make the evaluation a favorable one and fearing that it may not be. The relentless human need to pursue status can be held in check by hierarchies, but democracy, at least in principle, does away with political distinctions-which in turn releases the egalitarian drive and gives rise to factional struggle. Bourke brands this drive "democratic vanity." 114 The provenance of this analysis goes all the way back to Aristotle and Thucydides. It was this common intellectual heritage that Edmund Burke was tapping into when he predicted that erecting a regime of equality to govern over a commercial society would mean "there must be blood." Revolutionary France, he said, would succumb first to "civil war" and finally to the rule of "some popular general." 115

Recent research in the natural and social sciences supports this ancient wisdom about the dangers posed by democracy's core value. All the hunter-gatherer societies studied by anthropologists have been found on the whole to be egalitarian. Individuals still seek to raise their own status, but the rest of the community puts back in their place those who try to gain special treatment at the expense of others. Until some ten thousand years ago, when agriculture was invented, all the humans who had ever lived probably belonged to tribes that practiced the "reverse dominance" identified by Christopher Boehm. ${ }^{116}$ The result is that the mind has evolved to register unfairness in human relations and to seek out justice. This inference system often wins out over effortful logical reasoning, giving rise to an emotional need to have such "unfair" actions punished, even at a cost. ${ }^{117}$ To rework Gould slightly, a

\footnotetext{
109 Abdulkader Sinno, Organizations at War in Afghanistan and Beyond (Ithaca, 2008), 3.

${ }^{110}$ Jon Lawrence, Speaking for the People: Party, Language and Popular Politics in England, 1867-1914 (Cambridge, 1999), 4, 61, 267; James Vernon, Distant Strangers: How Britain Became Modern (Berkeley, 2014), 78-90.

${ }^{111}$ Mulholland, Northern Ireland at the Crossroads, 105-11.

112 Bourke, Peace in Ireland (2003), xviii, 301.

${ }_{113}$ Richard Bourke, "Pocock and the Presuppositions of the New British History," Historical Journal 53, no 3 (September 2010): 747-70, at 769.

114 Bourke, Peace in Ireland (2003), 301.

115 Richard Bourke, Empire and Revolution: The Political Life of Edmund Burke (Princeton, 2015), $677-739$.

${ }^{116}$ Christopher Boehm, Moral Origins: The Evolution of Virtue, Altruism, and Shame (Philadelphia, 2012), 49-74; David Sloan Wilson, Darwin's Cathedral: Evolution, Religion, and the Nature of Society (Chicago, 2002), 21-28, 119.

${ }^{117}$ Elise Seip, Wilco Van Dijk, and Mark Rotteveel, "Anger Motivates Costly Punishment of Unfair Behavior," Motivation and Emotion 38, no 4 (August 2014): 578-88.
} 
subjective appraisal that an informal social contract has been broken triggers most interpersonal violence. It is, to use the term coined by the biologist Robert Trivers, "moralistic aggression."118 So, when efforts to bring about a particular vision of democracy are frustrated-something that the difficulty of the questions posed by the concept makes nearly certain-a self-righteous fury can be set loose. If it cannot by cooled by either the political system or the constitutional setup, one or more organizations may well seek to assert their view of equality through a direct act of "the people." But, writes Bourke, "one rarely restores a democracy by means of revolution. More usually, one starts a civil war.”119

\section{CONFLICTS AND VIOLENCE IN BELFAST DURING THE SUMMER AND AUTUMN OF 1969}

On 7 June 1971, John McKeague a prominent Ulster loyalist and a founder of the Shankill Defence Association began giving evidence in camera to the Scarman Tribunal, which was inquiring into the civil disturbances two years earlier in which McKeague led attacks on people and property in west Belfast. Leslie Scarman had cleared the court "so that Mr. McKeague cannot suffer any prejudice." ${ }^{120}$ McKeague for his part was happy to inflict his own prejudices upon the tribunal, referring from the start of his answers to "Taigs," "Papists," and "Popeheads" and reveling in the chance to recount his violent deeds. Nonetheless, throughout a series of cross-examinations, he kept insisting that his passionate words and actions were based on principles of allegiance. McKeague was striving to defend "the Crown and Constitution" to which most of the population was loyal. "The majority ... always rules." However, he said, "under the British Constitution," minorities still had "the same political and civic rights and duties." "A Jew can come into this country," he explained, "[and] he can practise his religion and beliefs and still accept the Crown and the Constitution." So too could "any political or religious organisation." McKeague also conceded "the right of people in Northern Ireland to campaign by peaceful methods for a change in its Constitutional establishment." He was not fighting "Nationalists" but rather "rebels ... who have been using any force whatsoever-subversive-towards the Constitution.” McKeague's deeds were essentially acts of ideological violence. Moreover, he did what he did as only "a very small part" of "the people," who had "arisen" to "shake the Stormont Government ... into action that should have been taken."121 McKeague's use of religious slurs does not mean his behavior was an automatic emotional response; he was acting on the basis of legitimating conventions and denying that his opponents were doing the same. His extremism, then, was nothing other than an assertion of Bourke's democratic vanity. McKeague wanted his faction's vision of democracy to win out and he had been willing to use violence in pursuit of that goal.

\footnotetext{
118 Robert Trivers, "The Evolution of Reciprocal Altruism," Quarterly Review of Biology 46, no. 1 (March 1971): $35-57$, at 49 .

119 Bourke, Peace in Ireland (2003), 301, 303.

${ }^{120}$ Scarman Inquiry, Day 162, 7 June 1971, p. ii, IALS.

${ }^{121}$ Ibid., Day 162, 7 June 1971 (John McKeague), pp. 1, 48, 60-63, IALS; ibid., Day 163, 8 June 1971 (John McKeague), pp. 9-10, 27, IALS.
} 
The protagonists in the conflict on the streets of Belfast during the summer and autumn of 1969 all had opposing claims to democratic legitimacy. On 8 August, Home Secretary Jim Callaghan warned the Stormont cabinet that "the United Kingdom Government would have to demonstrate that it had final responsibility."122 A week later, Patrick Hillery, the minister of external affairs, paid a visit to Whitehall to press the Irish government's case for "your troops and ours [to] be combined together to form a peace-keeping force" and for "a constitutional conference." $\mathrm{He}$ "did not accept that the North was an internal matter for the United Kingdom"- "Northern Ireland is part of Ireland." 123 The leaders of the Unionist Party pushed back against what they saw in both cases as unwarranted interventions in their affairs. At a press conference on 17 August, Prime Minister James ChichesterClark pointed out that his government had "a parliamentary majority elected on 'one man, one vote." He argued that the "will" of the "sovereign authority of Westminster" must be balanced against that of "a majority of Ulster people." As for Dublin, Chichester-Clark compared its "deplorable" behavior to "those hooligans who have used the present troubles as an excuse to burn their neighbours out." Dublin's actions had worked to "inflame opinion," inspiring the "political Opposition," who were against "the very existence of the State," to turn Parliament into a "mere forum for wrangling." Of even greater concern was how this "very squalid business" had aided "the activities of extreme Republican elements."124 The IRA chief of staff portrayed the use of its "all too limited resources" as having been "an attempt to hold off the terrorist forces of reaction." These "legitimate" actions had been carried out by "the provisional government of the Irish Republic." 125

Due to an upsurge in grassroots organizing, the main actors found themselves joined on the political stage by a huge supporting cast. Local groups with a range of names-action committees, peace committees, defense associations, and so on-sprang up across Belfast, beginning in the west and north. Political activists were often involved, yet they were rarely in control. Although Republicans had helped to create the Ardoyne Citizens' Action Committee in late May 1969, a crowd of locals soon afterwards confronted them and forced them to resign from the committee. ${ }^{126}$ By the time the British army was committed, soldiers were marching into "a complicated and ever-shifting maze of street politics." 127 To a certain extent, as Sieyès had once feared happening to France, Belfast was breaking up

\footnotetext{
122 The National Archives of the United Kingdom (hereafter TNA), CJ4/46, Notes of a Meeting at the Home Office, 8 August 1969.

123 TNA, PREM13/284, Record of a Conversation between Lord Chalfont and the Minister of External Affairs, 15 August 1969; Report of Discussion at FCO London, 15 August 1969, DT2000/6/658, National Archives of Ireland.

${ }^{124}$ Speech by the Prime Minister, 17 August 1969, CAB/9B/312/1, Public Record Office of Northern Ireland (hereafter PRONI).

125 "IRA Moves Units in and Warns British Soldiers," Belfast Telegraph, 19 August 1969. See also, Republican Statement on Northern Crisis, 13 August 1969, DT2000/6/657, National Archives of Ireland.

${ }^{126}$ Deputation from Ardoyne Citizens' Action Committee to meet Belfast City Commissioner, 29 May 1969, D3233/7/5, PRONI; Scarman Inquiry, Day 59, 27 April 1970 (Gillespie), pp. 33-35, IALS.

127 TNA, DEFE/305, Narrative of the Military Operations in Northern Ireland Which Began in August 1969, vol. 1, III-12, Freedom of Information Act. See also TNA, WO305/3808, 39 Infantry Brigade Message, 20 August 1969.
} 
into little republics. ${ }^{128}$ The Ballymacarrett Citizens' Defence Committee sent representatives to negotiate with the authorities about "matters affecting the people." After a deal was reached, it "was presented to a meeting" and "approved unanimously." 29 Across the river, a number of groups were brought together by Jim Sullivan, the Belfast IRA's second in command, in the Central Citizens' Defence Committee. ${ }^{130}$ Republicans, however, could not control this umbrella body any more than they could the Ardoyne Citizens' Action Committee. Balancing them out was a church faction, which the hierarchy closely supervised. The Central Citizens' Defence Committee was so split that its members frequently allied themselves with a range of outsiders in their attempts to get their way. ${ }^{131}$ Important decisions, such as whether to put up or to take down barricades, had to be made independently by local committees. ${ }^{132}$ On the Shankill Road, there was not even the appearance of unity, with factions openly contesting each other's claim to speak for "the people." McKeague's Shankill Defence Association competed with, among others, Ian Paisley, a Unionist-led peace committee, the Workers Committee for the Defence of the Constitution, and a group of "mothers."133

Organizations — old and new, big and small—mobilized people, provided them with the chance to participate, and coordinated their actions. The Shankill Defence Association elected officers, took membership subscriptions, and held weekly meetings. Army intelligence "suspect[ed]" that most Shankill Defence Association members were "self-styled 'leaders' of their areas" and noted how they "represented" the "views and complaints" of those neighborhoods. ${ }^{134}$ On the streets, John McKeague and his "Headquarters party" directed attacks by giving orders to a team of lieutenants and addressing crowds with loudhailers. ${ }^{135}$ Militant organizations also exercised command and control over the airwaves; the morning after 39 Infantry Brigade deployed, an armored car picked up IRA communications on its radio. ${ }^{136}$ The following month, the pirate station Radio Orange asked its listeners to carry transistor radios so that it could send them to where clashes were taking place. ${ }^{137}$ After Radio Free Belfast was jammed, Republicans adapted by putting up posters along the Falls Road urging people to "reinforce their barricades."138

\footnotetext{
${ }^{128}$ Hont, "Permanent Crisis of a Divided Mankind," 199-200.

129 "E. Belfast Security Plan," Irish News, 17 September 1969.

130 TNA, WO305/3808, Report on a Meeting with the Central Defence Committee, 27 August 1969.

${ }^{131}$ Joint Security Committee Conclusions, 5 September 1969, HA32/3/2, PRONI; Cabinet Conclusions, 15 September 1969, CAB4/1475, PRONI; TNA, WO305/4191, 39 Infantry Brigade Duty Officer's Log (hereafter 39 Log), 16 September 1969; Military Intelligence Reports, n.d. [early September 1969], DT2000/6/660, National Archives of Ireland.

${ }_{132}$ TNA, CJ3/18, Narrative of Events, 15 September 1969.

${ }^{133}$ Joint Security Committee Conclusions, 25 August 1969, HA32/3/2, PRONI; "Workers Defend Links with Britain," Belfast Telegraph, 26 August 1969; "Shankill Gets Peace Group," Belfast Telegraph, 9 September 1969; TNA, WO305/4192, 39 Log, 17 October 1969.

${ }_{134}$ TNA, WO305/4192, Record of a Meeting of the Shankill Defence Association, 30 October 1969.

135 Scarman Inquiry, Day 160, 19 May 1971 (John McKeague), pp. 38, 47, 49, 51, 66, IALS; "Defence Association in Shankill," Belfast Telegraph, 1 May 1969.

136 TNA, WO 305/3808, 39 Log, 16 August 1969.

137 TNA, CJ4/425, Illegal Broadcasting Stations, 4 September 1969; TNA, CJ4/425, Report from Superintendent Hill, 8 September 1969.

138 TNA, WO305/3809, 39 Infantry Brigade INTSUM, 19 September 1969.
} 
Riots, as a military analysis concluded, were produced by a "militant, extremist leadership."139

By the middle of September 1969, the general officer commanding, the Royal Ulster Constabulary Special Branch, and the Joint Intelligence Committee had all agreed that the Shankill Defence Association and the Ulster Volunteer Force were most likely to be the authors of the next "major" disorder. ${ }^{140}$ During early October, reports came in that both organizations were indeed planning multiple demonstrations to stretch the security forces and that Loyalists had smuggled a cache of arms in from Sweden. The pretexts for taking to the streets were rumored to be the use of CS gas, McKeague's arrest, and soldiers fraternizing with local women. Finally, on the night of 10-11 October, Special Branch received solid intelligence that the Loyalist plan to "confront" the military was about to be put into action. Starting with women and children sitting down in the way of lunchtime traffic, the sequence of protests kept closely to the timetable acquired by Special Branch ("Next performance scheduled for 1800"). As the day got darker, the Royal Ulster Constabulary struggled to shield Unity Flats-seen by Loyalists as an IRA citadel-from a crowd of around two thousand men. With the pubs letting out Saturday-night drinkers, the police called in the army. Missiles were met with CS gas, smoke drew gunfire and petrol bombs, and automatic weapons were countered with armored vehicles. The battle between British soldiers and suspected exservicemen went on until dawn, by which time Loyalists had let loose in excess of a thousand rounds. Following up their advantage, the security forces carried out a search operation later that morning. It captured "two petrol bomb factories, a small supply of arms and ammunition, and equipment and literature belonging to Radio Loyal Ulster."141

"Events," the 39 Infantry Brigade INTSUM judged, "had been pre-planned."142 Yet the scholarly consensus is that the protests and violent acts were largely spontaneous, an emotional reaction from "Protestant Belfast" to the publication of the Hunt Report on policing, not least its proposal to do away with the Special Constabulary. ${ }^{143}$ This distorted view is the result of inadvertently looking at developments through a national or ethnic optic. ${ }^{144}$ Historians have to work with the traces of the past that survive into the present, and activists have worked hard to construct narratives that endure. Writing about imperial Austria, Judson shows how nationalist

${ }^{139}$ Lieutenant-Colonel Sibbald, Crowd Control, 5 December 1969, 79/33/3, Imperial War Museum.

140 Talk to Commanders at GOC's Conference, 2 September 1969, 79/33/3, Imperial War Museum; Narrative of Military Operations, IV-5.

${ }^{141}$ TNA, WO305/4192, $39 \log , 5,7,10$, and 11 October 1969; TNA, WO305/4231, 39 Infantry Brigade (Rear) "G” Log, 10-12 October 1969; TNA, WO305/4192, 39 Infantry Brigade INTSUM, 20 October 1969; Report by OC 3 LI of Operations on the Shankill Road, 11-12 October 1969, reproduced in Narrative of Military Operations; Statement of Head Constable Stewart, 10 December 1969, BELF6/1/1/23, PRONI; "Worst Fighting since 1922," Belfast Telegraph, 13 October 1969.

142 TNA, WO305/4192, 39 Infantry Brigade INTSUM, 20 October 1969.

${ }^{143}$ Andrew Sanders and Ian Wood, Times of Troubles: Britain's War in Northern Ireland (Edinburgh, 2012), 6; Simon Prince and Geoffrey Warner, Belfast and Derry in Revolt: A New History of the Start of the Troubles (Dublin, 2011), 220; Paul Bew, Ireland: The Politics of Emnity 1789-2006 (Oxford, 2007), 497; Patterson, Ireland since 1939, 217; Hennessey, Northern Ireland, 309.

${ }^{144}$ Gary Wilder, "Unthinking French History: Colonial Studies beyond National Identity" in After the Imperial Turn: Thinking with and through the Nation, ed. Antoinette Burton (Durham, 2003), 125-43, at 127,132 . 
politicians and journalists kept recasting incidents that were "structured, limited, and planned" as evidence of "widespread" and "enduring" "nationalist frustration." The logic of this interpretation, then, was that different communities had to be kept apart or they would tear each other apart - and it was "so flawless that most historians have agreed with it." 145 Much the same has happened in modern Irish historiography. Loyalist weakness at the start of the Troubles has thus been mistaken for strength. The Shankill's self-proclaimed defenders for their own partisan purposes had chosen to bring the war home to an area that was "relatively peaceful." They were producing violence to build support. Other people certainly did join the Shankill Defence Association and Ulster Volunteer Force to confront the security forces, but they were mostly drunks, petty criminals, and curious onlookers, who drifted away when the gunmen began to use them as human shields. ${ }^{146}$ As for the young women whose honor the Loyalists were guarding, "girls returning home from a dance" told reporters "they would have to spend the night in the street." 147 The relationship between Loyalist organizations and the individuals they claimed to represent was at best ambiguous and at worst abusive and absurd. It was the same with Republicans: in Ballymurphy, for instance, the IRA intimidated locals who owned licensed firearms into handing the guns over to "their" defenders. ${ }^{148}$

The writer Hugh Shearman noted how "modern inventions" were making the street fighting very different from that which he had witnessed in the 1920s. He picked out as examples "the materials for making petrol bombs" and the transistor radios "for rallying support for a riot." 149 The movement of people, goods, and ideas was, as usual, driving change. But by the late 1960s, Belfast had been integrated into a different "Market Empire" - the web of networks traced by America's power and influence in the world. A conveyor belt of innovative products, Washington's championing of free trade, and the dynamic marketing campaigns of American firms enmeshed Western Europe in consumer-oriented capitalism. ${ }^{150}$ The global vectors that came together as they passed through the local terrain of Belfast created not only new street-fighting techniques but also new spaces for the fighting and new identifications for those on the streets. Tower blocks, housing estates, motorways, airwaves, nightclubs, and an expanded university became sites of conflict. Moving from place to place and hanging out in specific spots across this urban landscape were teenagers who, through consumption, had imagined themselves into a global youth culture. Young women wore miniskirts on both the Falls Road and the Shankill Road, and Belfast had grown its own beat-music scene. ${ }^{151}$ New fashions, music, and lifestyles offered ways of engaging in self-invention;

145 Judson, Guardians of the Nation, 10, 178-80, 215-18.

146 TNA, WO305/4192, 39 Infantry Brigade INTSUM, 20 October 1969; Report by OC 3 LI of Operations on the Shankill Road, reproduced in Narrative of Military Operations; "Court 'Doubles-Up' after the Week-End," News-Letter, 14 October 1969.

147 "Worst Fighting since 1922," Belfast Telegraph, 13 October 1969.

148 TNA, WO305/3809, 39 Log, 20 September 1969.

149 "Do We Need a Shock?," News-Letter, 17 September 1969.

${ }^{150}$ Victoria De Grazia, Irresistible Empire: America's Advance through Twentieth-Century Europe (Cambridge, MA, 2005); John Lyons, America in the British Imagination: 1945 to the Present (Basingstoke, 2013), 1-34.

151 "It's Mini-Skirts as Usual," Belfast Telegraph, 19 August 1969; "Peace Is Tops of the Pop Parade," News-Letter, 2 August 1969. 
democracy's egalitarian drive led individuals in a variety of subcultures to struggle for the freedom to be their authentic selves. ${ }^{152}$

During the summer of 1969, Father Marcellus Gillespie, who liked to wear black jeans and a leather jerkin, tried to harness youth culture to counter the activities of Republicans and Loyalists. On 2 August, Gillespie, along with two nightclub promoters, a music journalist, and a Labour politician, staged the free Pop for Peace festival for a crowd of at least five thousand in parkland ringing the city. John Lennon and Yoko Ono sent a telegram from their Montreal bed-in ("All we are saying is give peace a chance"), BBC Radio 1 lent support, and the chart-topping Marmalade headlined the event. More teenagers danced at Pop for Peace that afternoon than rioted in west and north Belfast that night. In that violence, Shankill Defence Association members were the prime movers; the organization had earlier tried to intimidate the National Trust into backing out of hosting the festival. For Loyalists, Pop for Peace was not just a threat to their street politics: it was also part of a plot orchestrated by Lennon and Moscow to overthrow Stormont. ${ }^{153}$

While this fear was fanciful, leftists-who were themselves more of a "scene" than an organization or movement - did indeed have hopes that youth culture could work as a bridge to political involvement. The newssheets and radio programs they produced from behind the barricades of Free Belfast drew upon the words, sounds, and images of international counterculture. A satirical attack on two Special Branch officers, for instance, ended with "the boys in Hooker Street" asking to hear "Gratefully Dead" by the psychedelic-rock band Eric Burdon and The Animals. ${ }^{154}$ Leftists attempted to argue that political concerns, too, had become transnational. "The human rights we are seeking are the rights people all over the world are entitled to," declared the Citizen Press, "whether he be the negro in America [or] the Czech in the face of Russian Imperialism."155

Connections, concrete and imagined, could cause understandings of space to expand to encompass the globe, but they could also lead them to shrink down to a single street. "We were born and raised with each other up here," said one interviewee in an article on The Bone and Louisa Street from early August 1969. "It's like a family." 156 West and north Belfast was made up of many such spaces. Shopkeepers, publicans, and bookmakers lived together with workers, and in some districts, including The Bone and Louisa Street, so too did people of different Christian denominations. Religious divisions did not in and of themselves produce conflict. A woman whose husband was both an engineer and a B Special gave

152 Timothy Scott Brown, West Germany and the Global Sixties: The Antiauthoritarian Revolt, 1962-1978 (Cambridge, 2013); Selina Todd and Hilary Young, "Baby-Boomers to 'Beanstalkers': Making the Modern Teenager in Post-War Britain," Cultural and Social History 9, no. 3 (May 2012): 451-67; Billy Liar, November 1968, D3219/3, PRONI; Defamator, nos. 1-4, D3219/3, PRONI.

${ }_{153}$ Scarman Inquiry, Day 59, 27 April 1970 (Gillespie), pp. 39-40, IALS; Scarman Inquiry, Day 60, 28 April 1970 (Father Marcellus Gillespie), pp. 31, 44-6, IALS; Scarman Inquiry, Day 160, 19 May 1971 (McKeague), pp. 48, 72-77, IALS; “The Peace Seekers," News-Letter, 4 August 1969; "Martial Law in Belfast 'A Distinct Possibility," Irish News, 4 August 1969; "Unionist 'Regrets' 1969 Gig Letters," News-Letter, 2 August 2009.

${ }^{154}$ TNA, CJ4/425, Extracts from Pirate Radio Broadcasts, 4 September 1969; "Behind the Barricades," Irish News, 11 September 1969.

155 Citizen Press, 30 August 1969, D3297/1, PRONI.

156 "Catholic and Protestant Work for Peace in Area," Irish News, 8 August 1969. 
evidence to the Scarman Tribunal that she would go to the launderette on Clonard Gardens off the Falls Road every Monday and have "fine good times" "gossiping" with her "Roman Catholic neighbours." "57 Further north, on a small street close to the Shankill Road, a Roman Catholic mother told an American interviewer that her "Protestant neighbors" were "good women" and that her daughters "play[ed] with Protestants." 158 In Ardoyne, older children and teenagers mixed socially at an interdenominational youth club. ${ }^{159}$ While a lot more research remains to be done here, the evidence does suggest that these were situational communities based on place rather than class or religious identifications. For a Roman Catholic man from Leopold Street who worked and drank with Protestants from the Shankill, Orange parades were just "a seasonal thing, it was like water going off a duck." His family's everyday life was usually "happy." 60 The members of these communities looked out for each other, sharing the struggle against the common threats of poverty and insecurity. A woman from Hooker Street recalled at the Scarman Tribunal how her family cared for a sick man who lived a few doors down and took in a girl when her mother worked weekends - even though both these people subscribed to a different faith from that of her family. ${ }^{161}$ Formal institutions may have been organized on a denominational basis, but informal institutions could cross the religious divide. Like residents of northern England's industrial towns and London's deprived districts, most of those who dwelled in Belfast's communities of place saw the urban landscape as functional and constraining. They did not separate out the social and cultural from the spatial nor see individuals as social and cultural products. ${ }^{162}$

The "ordinary" people of such places did not turn on each other during the summer and autumn of 1969-at least, not at first. ${ }^{163}$ In The Bone and Louisa Street, men from a range of backgrounds volunteered for a "lay security force."164 Sandy Row's peace committee "collaborated well" with its counterpart in the abutting Markets district, and both "worked together" to keep order. ${ }^{165}$ In the Docks area, an action committee made up of both Roman Catholics and Protestants took responsibility for "patrolling the streets," where "neighbours are still on the mostfriendly terms." Belfast's "peace corps" were set up to try to shield their communities against the attacks by political activists coming from outside. ${ }^{166}$ A mixed group of vigilantes stopped vehicles traveling along Ardoyne's Alliance Avenue because, its spokesman explained, "We don't want any guns taken into our area."167

157 Scarman Inquiry, Day 158, 17 May 1971 (Elizabeth Scott), pp. 16-19, IALS.

158 "In Belfast, the Time of Troubles Becomes a Family's Way of Life," New York Times, 13 October 1969

${ }^{159}$ Scarman Inquiry, Day 53, 15 March 1970 (Ailbe Delaney), pp. 85-86, IALS.

${ }^{160}$ Ibid., Day 50, 6 March 1970 (Anthony Dunham), pp. 62, 70, IALS.

${ }^{161}$ Ibid., Day 50, 6 March 1970 (Ann Dunville), pp. 45-6, IALS.

${ }^{162}$ Gillian Evans, "What about White People's History': Class, Race, and Culture wars in contemporary Britain," in Culture Wars: Context, Models, and Anthropologists' Accounts, ed. Deborah James, Evelyn Plaice, and Christina Toren (Oxford, 2010), 115-30, at 120, 122; Mike Savage, Identities and Social Change in Britain since 1940 (Oxford, 2010), 35-36, 47, 222.

163 Savage, Identities, 221-22.

164 "Catholic, Protestant Peace Corps," Irish News, 6 August 1969.

165 Government of Northern Ireland, Violence and Civil Disturbances in Northern Ireland in 1969 (Belfast, 1972), 222.

166 “'We Want Peace' Plea from Catholic and Protestant," Irish News, 9 August 1969.

167 "City Peace behind Barb-Wire," Belfast Telegraph, 18 August 1969. 
"I don't fear a mob," said "Paddy" to the Belfast Telegraph in early August, "but when they have meetings and walk up the street making a list of houses to be cleared, it is different." His "heartbroken" Protestant neighbors had tried to help his family, but they too were "threatened." 68 McKeague almost certainly burned Elizabeth Gilmour out of her house in Ardoyne, so that he could blame "rebels" for the outrage and justify taking reprisals. ${ }^{169}$ (One of her Roman Catholic neighbors secured Gilmour's damaged property to keep out looters.) ${ }^{170}$ Republicans were also menacing some of the people they had vowed to defend. During early August, an IRA-front organization advised a number of families on Hooker Street to leave for their own safety and provided a truck for them to move their furniture. Soon afterwards, many of these families returned to their homes. ${ }^{171}$ A Roman Catholic widower who did not want to leave the house in the Shankill he had lived in "for most of his 71 years" had his windows boarded up by three local men ("I believe in the text 'Love thy neighbour"'). ${ }^{172}$ Groupness events usually involved neighbors coming together to support each other; different communities were not in conflict.

Across the river in east Belfast, where the fighting of the 1920s had begun, this pattern was much more pronounced. On 19 August, the Guardian's Simon Hoggart found Roman Catholics and Protestants "visiting each other, exchanging news and cups of tea." Hoggart credited the East Belfast Peace Committee with keeping these "friendship[s] warm." 173 This self-styled "army of moderation" drew its three hundred or so volunteers from, in the words of one of them, "all classes, all denominations, old people and young people, and all political opinions." It put on nightly street patrols, organized a drop-in center, ran a twenty-four-hour telephone help line, produced a bulletin to counter rumors, and collected twelve thousand signatures for a "peace petition." The chair of the committee had strong links to the shipyard trade unions, which were encouraging their members to continue to get along with each other both inside and outside of work. ${ }^{174}$ At a meeting called by the shop stewards on 15 August, thousands of workers passed a resolution expressing their "determination to maintain peace and good will."175 The police officer in charge of the area praised the trade unions at the Scarman Tribunal for ensuring there was "no violence of any kind between opposing factions or individuals in the shipyard." 176

As the situation continued to deteriorate in north and west Belfast, however, acts of resistance gave way to making the movement of people more orderly and less violent. Committees backed by clergy from a range of denominations oversaw

168 "You Want to Know What It's Like to Be Forced Out of Your Home?," Belfast Telegraph, 8 August 1969.

169 Scarman Inquiry, Day 50, 6 March 1970 (J. Dineen), p. 62; Scarman Inquiry, Day 59, 27 April 1970 (Gillespie), pp. 37, 63, IALS; Scarman Inquiry, Day 160, 19 May 1971 (McKeague), p. 53, IALS.

170 Scarman Inquiry, Day 46, 2 March 1970 (Vivian Simpson), p. 32, IALS.

${ }^{171}$ Ibid., Day 46, 2 March 1970 (Sansom), p. 66, IALS.

172 "How the Terror Hits the Innocent," News-Letter, 16 August 1969.

173 "Peace Walkers Defuse Threats," Guardian, 20 August 1969.

174 TNA, CJ3/57; Hunt Committee Meeting with East Belfast Peace Committee, 9 September 1969; "All East Belfast Joins in Bid for Peace," 1 September 1969, News-Letter; "In Pursuit of Peace," Irish Times, 8 October 1969.

175 "Shipyard Men Unite to Set 'Peace' Example," News-Letter, 16 August 1969.

176 Scarman Inquiry, Day 164 (Henry Shute), p. 44, IALS. 
exchanges of houses, and ministers opened up their churches and halls to provide shelter for those with nowhere to go. Neighbors watched over property left behind and helped to redecorate new homes. ${ }^{177}$ In Dover Street, next to the Shankill Road, the leader of the local vigilantes, a grocer, blocked squatters from taking over the furnished Cunningham house to give his regular customers the chance to return. Lily MacNeill, who had "Protestant in her own family," did return to her home in nearby Ardmoulin Avenue-but, she told an American reporter, "I don't see how I can stay." 178 Violence had broken up neighborhoods. On 19 August, "an Ardoyne resident" "took a long walk through the district where [he] was born and reared" and "got the impression many friendships have been lost."179

Belfast's neighborhoods were like families - and like families, they had their conflicts. On the streets of the city, both the pursuit of status and the scrutiny of behavior were open, daily, and intense. ${ }^{180}$ This scrutiny produced conflicts, which sometimes became violent. The Troubles greatly increased the likelihood of intimate violence, as the disruption made it more difficult for individuals to coordinate their understandings of the world with each other. Efforts to address the problem through gossip only served to undermine civic cohesion further. ${ }^{181}$ Rumors scared people into fleeing their areas, deceived them into supporting the stratagems of militant organizations, led them to suspect public services, and made them distrust information provided by the media and the authorities. The 39 Infantry Brigade started running an internal "rumour of the week" competition; the winning story one week was that Loyalists were tunneling under Unity Flats. ${ }^{182}$

Individuals who experienced moralistic aggression-a desire to punish someone for breaking an informal social contract-could choose to take direct action against their targets. With some people believing local communities needed to police themselves, outsiders-especially alleged child abusers-received verbal threats and physical assaults. Intimate violence arising out of seemingly trivial matters was much more common. ${ }^{183}$ A man feuding with his neighbors in the Shankill set his dog on them, and a dispute over car parking in Clonard led to a threat of slashed tires. Tensions within one family living in Ardoyne turned violent when a man set fire to his mother-in-law's clothes. The connections between intimate violence and the overarching conflict could be direct too. Vigilante patrols sometimes quarreled among themselves, and these rows could escalate quickly from exchanging insults to trading punches to firing bullets. ${ }^{184}$

\footnotetext{
177 Ibid., Day 48, 4 March 1970 (O’Donnell), pp. 51-52, IALS; ibid., Day 59, 27 April 1970 (Gillespie), p. 64, IALS; "Creating Centres of Peace," Irish Times, 27 August 1969.

178 "In Belfast, One Incident Is Viewed 3 Conflicting Ways," New York Times, 28 August 1969.

179 "Ardoyne: Fears That Things Will Never Be the Same," Irish News, 20 August 1969.

${ }^{180}$ Kalyvas, "Conflict," 608.

${ }^{181}$ Maureen Healy, Vienna and the Fall of the Habsburg Empire: Total War and Everyday Life in World War I (Cambridge, 2004), 122-59; Clonard Monastery Domestic Chronicle, September 1969.

182 "Exodus Builds Up after IRA Threat," Belfast Telegraph, 19 August 1969; TNA, WO305/3808, 39 Log, 20, 24 August 1969; TNA, WO305/4193, 39 Log, 14 November 1969.

${ }^{183}$ John D. Brewer, Bill Lockhart, and Paula Rodgers, Crime in Ireland 1945-95: 'Here Be Dragons' (Oxford, 1997), 21, 44, 92, 94, 214, 220.

${ }^{184}$ TNA, WO305/3809, 39 Log, 13 September 1969; TNA, WO305/4231, Infantry Brigade (Rear) "G" Log, 17 and 28 October 1969; TNA, WO305/4193, 39 Log, 18 November 1969; "Clothing Fire," Belfast Telegraph, 19 September 1969.
} 
By far the most popular way of trying to put someone back in their place, though, was to use the communication networks provided by state agencies. "The spate of threatening telephone calls and letters," recorded the 39 Infantry Brigade INTSUM for the start of September 1969, "now embraces the whole of Belfast." 185 Every neighborhood in the city, regardless of its religious or class makeup, was conflictual; however, only those districts where the British army and paramilitary groups were present had serious incidents of interpersonal violence. Moralistic aggression could be expressed indirectly here through one or more of these organizations. Pirate radio stations delivered numerous threats to named individuals over the airwaves. ${ }^{186}$ The army received tip-offs from the public that sent soldiers across west and north Belfast on raids; the usual result was simply a terrorized household. ${ }^{187}$

The politicization of private life and the privatization of politics had a heavy impact on young women. ${ }^{188}$ That so many people came to believe a rumor that the army had set up "courting facilities in troubled areas of the city" was a reflection of how strong the sense of sexual threat was. ${ }^{189}$ These concerns were not entirely without substance; a few soldiers did prey upon underage girls. ${ }^{190}$ Nonetheless, some individuals were using claims that they were defending virtue to justify dealing out violence. Over the course of autumn 1969, two teenagers with boyfriends in the army had their hair cut off; one had it done to her by her own mother and attempted suicide afterwards. ${ }^{191}$ The Troubles handed domestic abusers excuses and weapons: this was what a judge ruled in the case of a man who had hurled a petrol bomb at his long-term girlfriend's home (he missed and set fire to another house). ${ }^{192}$ However, the Troubles also offered women in violent relationships ways of fighting back, as they could now enlist soldiers in their defense. The army was called upon to get property back from a former boyfriend, to evict a man just out of prison who had kicked in the door to his wife's house, and to "keep an eye" on an abusive husband. Exploiting the premium on information, one woman telephoned in a tip that her IRA boyfriend kept guns at home and had robbed a Dublin bank. ${ }^{193}$

The blending of public and private was at play in the activities of paramilitaries too. Individual state agents were typically targeted for personal reasons as well as for the uniform they wore. Former prisoners with long memories stabbed a retired guard,

\footnotetext{
185 Scarman Inquiry, Complaints and Reports to RUC of Threats and Intimidations, Belfast Exhibits No 21, IALS; TNA, WO305/3809, 39 Infantry Brigade INTSUM, 8 September 1969.

186 TNA, CJ4/425, Extracts from Pirate Radio Broadcasts, 4 September 1969.

187 TNA, WO305/3808, 39 Infantry Brigade INTSUM, 30 August 1969; Narrative of Military Operations, III-13; Fr Pat Egan, "Devastation in Clonard Area-By an Eyewitness," n.d., Clonard Monastery, Belfast, photocopy extracts from archive and house chronicles.

188 Kalyvas, "Ontology of 'Political Violence," 485.

189 "GOC Shoots Down 'Courting Room' Report,” Belfast Telegraph, 23 October 1969.

190 "Watching All the Girls Go By," Belfast Telegraph, 29 August 1969; TNA, WO305/4192, 39 Log, 28

October 1969; TNA, WO305/4193, Infantry Brigade (Rear) "G” Log, 23 November 1969.

191 TNA, WO305/4231, Infantry Brigade (Rear) “G” Log, 21 October 1969; TNA, WO305/4193, 39

Log, 12 November 1969.

192 "Petrol Bomb Man Gets Three Years," Belfast Telegraph, 19 September 1969.

193 TNA, WO305/3809, 39 Log, 25 September 1969; TNA, WO305/4192, 39 Log, 2 October; TNA, WO305/4193, 39 Log, 7 and 20 November 1969.
} 
the Shankill Defence Association sought revenge on a corporal who had struck Loyalists with his rifle butt, and the army had to rescue a "despised" Royal Ulster Constabulary man before he was shot on the Falls. ${ }^{194}$ Pubs were attacked by militants because they were the headquarters for rival groups, but also because they were business competitors and stocked with liquor to loot. ${ }^{195}$ In the neighborhoods that militant organizations were seeking to control, claims on money and goods came with the promised protection. East Belfast shopkeepers had to "subscribe to the vigilantes' tea fund" and residents of the Falls had to provide packs of cigarettes. ${ }^{196}$ While some were taking, however, others were giving back: Jim Sullivan returned lots of stolen goods, including a submachine gun belonging to the Royal Hampshire Regiment. ${ }^{197}$ The mixture of motives held by paramilitary members was different for each individual, and they varied across both time and space. What appears to have been common to most people in most moments, though, was the pride taken in participating with others in a struggle against great injustice. Processes mattered more than outcomes. ${ }^{198}$ There were no rational, self-interested actors in the militant organizations fighting in Belfast.

The first British soldier shot dead during the Troubles does not appear in Lost Lives: The Stories of the Men, Women and Children Who Died as a Result of the Northern Ireland Troubles. Craftsman Christopher Edgar is absent from the book because he chose to kill himself. ${ }^{199}$ Before his suicide on 14 September 1969, Edgar had written home that the tour had left him feeling "like a zombie." 200 Six weeks later, another soldier with depression had a psychotic episode; he climbed on to the roof of Albert Street mill, took off his uniform, and fired his rifle toward the Lower Falls. Thanks to Sullivan's cooperation, the army was able to contain the situation and convince the soldier to leave the roof without anyone getting hurt. ${ }^{201}$ Internal conflicts such as those endured by these two men disrupted emotional regulation, which in turn made aggression and violence much more likely. ${ }^{202}$ Troubled minds played a part in producing the violence of the Troubles, and the violence of the Troubles played a part in producing troubled minds. As early as the end of August, family doctors were "flooded" with patients suffering from depression, anxiety, and

194 TNA, WO305/4192, 39 Log, 3, 16, and 17 October 1969.

195 TNA, WO305/3809, 39 Infantry Brigade INTSUM, 14 September 1969; TNA, WO305/3809, 39

Log, 2 and 5 September 1969; Scarman Inquiry, Licensed Premises, Belfast Exhibits No 20, IALS.

196 “"Vigilantes' Operating Protection Rackets," News-Letter, 10 September 1969; TNA, WO305/3809, $39 \mathrm{Log}, 11$ and 12 September 1969; TNA, WO305/3809, 39 Infantry Brigade INTSUM, 14 September 1969; TNA, WO305/4192, 39 Infantry Brigade INTSUM, 29 October 1969.

197 TNA, WO305/4193, 39 Log, 1 and 26 November 1969.

198 Elizabeth Wood, Insurgent Collective Action and Civil War in El Salvador (Cambridge, 2003), 16-19, 229-47; Ana Arjona and Stathis Kalyvas, "Recruitment into Armed Groups in Colombia: A Survey of Demoralized Fighters," Understanding Collective Political Violence, ed. Yvan Guichaoua (Basingstoke, 2012), 143-71.

${ }^{199}$ Chris Thornton, Seamus Kelters, Brian Feeney, and David McKittrick, Lost Lives: The Stories of the Men, Women and Children Who Died as a Result of the Northern Ireland Troubles, rev. ed. (Edinburgh, 2007).

200 "Shot Soldier Wrote Home," Belfast Telegraph, 15 September 1969; TNA, WO305/3809, 39 Log, 14 September 1969.

201 NIREP, 2 November 1969, TNA, WO305/4193.

202 Seena Fazel et al., "Depression and Violence: A Swedish Population Study," Lancet Psychiatry 2, no. 3 (March 2015): 224-32. 
dissociative disorders. Another familiar way of coping with hidden harm-teenage fire-setting-became a problem the following month. ${ }^{203}$

The Troubles, even in its first year, was a constellation of conflicts. Some were confined within a single head, while others stretched across the globe; some were lonely struggles, others affected millions of people; some were over in minutes, others lasted decades. These multiple dynamic and intersecting conflicts were arrayed around a central conflict: that of rival conceptions of democracy. It was when this conflict turned violent-a difference in kind, not of degree-that violence started to be deployed much more in other conflicts as well. The violent conflict between organizations strained relationships, disrupted normal policing, and tempted feuding individuals to lash out indirectly through state agencies and paramilitaries.

Civil war broke buildings, bodies, and brains. But the violence of the Troubles was creative as well as destructive: individuals and organizations responded to it by constructing new identifications, institutions, and ideas. These processes had logics of their own, giving rise over time to conflicts that were barely connected to those charted in this section. The original issue in contention, however, was not marginalized. Indeed, the conflict over the meaning of popular sovereignty has continued to structure public life into the peace-process era.

\section{CONCLUSION}

The Ml motorway was carved through west Belfast at the end of the 1950s and the start of the 1960s. Its planners had set out to make traveling to and from the center quick and easy. In a similar fashion, ethnic readings of the Troubles have promised a simple way to cover ground in a short space of time. ${ }^{204}$ When moving at such speeds, the complex interactions of the local and the transnational, the individual and the collective, and the personal and the political going on in the surrounding streets blur into a single conflict. It looks as if whole communities have been struggling for mastery.

Residents of west Belfast were largely powerless to stop the Ml from being built, but stopping the traffic gave them some power. From the summer of 1969 onwards, sit-down protests and barricades regularly closed motorway junctions. ${ }^{205}$ This article, likewise, is an attempt to disrupt the smooth flow of the ethnicity freeway. Slowing scholars down gives them a chance to look more closely at what happened in the city's neighborhoods. And once the complicated patterns have been spotted amid the rows of houses and blocks of flats, those who find them, hopefully, will not be blind to them again.

203 "Riot Sick Make a Rush to the Doctor," Belfast Telegraph, 25 August 1969; TNA, WO305/3809, 39 Log, 21, 23, and 30 September 1969; "Children as Fire-Raisers Theory,"News-Letter, 23 September 1969; "Youth Is Jailed on Arson Charge," Belfast Telegraph, 23 October 1969.

${ }^{204}$ This metaphor is adapted from Bruno Latour, Reassembling the Social: An Introduction to ActorNetwork-Theory (Oxford, 2005), 35.

205 TNA, CJ3/38, Security Situation, 5 September 1969. 